\title{
Penerapan transfer learning pada convolutional neural networks dalam deteksi covid-19.
}

\author{
Buyut Khoirul Umri*1 dan Visq Delica ${ }^{2}$ \\ 1 Universitas AMIKOM Yogyakarta \\ Jl. Padjajaran, Ring Road Utara, Kel. Condongcatur, Kec. Depok, Kab. \\ Sleman, Prop. Daerah Istimewa Yogyakarta \\ buyut.u@students.amikom.ac.id \\ 2 Universitas AMIKOM Yogyakarta \\ Jl. Padjajaran, Ring Road Utara, Kel. Condongcatur, Kec. Depok, Kab. \\ Sleman, Prop. Daerah Istimewa Yogyakarta \\ visq.delica@students.amikom.ac.id
}

\begin{abstract}
Abstrak
Pandemi Covid-19 menjadi masalah serius di dunia termasuk Indonesia sampai saat ini, virus yang muncul pada akhir tahun 2019 ini masih menjadi masalah serius. Jumlah kasus orang yang terinfeksi terus meningkat dan mencapai angka lebih dari dua ratus juta kasus di seluruh dunia. Untuk melakukan tes cepat deteksi Covid-19 ini tidak langsung dapat berjalan dengan lancar tetapi mengalami banyak kendala yang dialami oleh tim medis. Salah satunya pemnyebabnya adalah keterbatasan kit tes Covid-19, sehingga ilmuwan mengambil langkah diagnosis lainnya. Dalam bidang informatika, ilmuwan banyak menggunakan beberapa diagnosis salah satunya gambar X-ray pada paru-paru. Gambar CXR pada saat ini sering digunakan untuk proses deteksi menggunakan algoritma CNN. Penelitian ini menggunakan metode transfer learning yang akan diuji dalam dataset skala besar dan kecil. Hasil terbaik dari semua model yang dicoba yaitu MobileNet dengan hasil akurasi $98.11 \%$ yang diuji pada dataset skala besar dan paling rendah didapat oleh ResNet50 yang diuji pada dataset skala kecil dengan akurasi 41.94\%. Dataset dalam skala besar juga menjunjukkan peningkatan akurasi pada semua model transfer learning yang diuji.
\end{abstract}

Kata Kunci cnn, transfer learning, x-ray, covid-19

\section{Pendahuluan}

Pandemi Covid-19 menjadi masalah serius sampai saat ini di dunia tidak tekecuali do Indonesia [1;2], virus yang muncul pada akhir tahun 2019 ini masih menjadi masalah serius. Jumlah kasus orang yang terinfeksi terus meningkat dan mencapai angka lebih dari dua ratus juta kasus di seluruh dunia [3]. Covid-19 tidak hanya dalam penyebarannya yang meningkat tetapi juga bermunculan berbagai variasi jenis virus ini yang semakin berbahaya. Dalam hal ini tes cepat untuk deteksi Covid-19 menjadi metode yang masih efektif untuk mengetahui seseorang terkena Covid-19 atau tidak. Untuk melakukan tes cepat ini tidak langsung berjalan dengan lancar tetapi mengalami berbagai kendala, salah satunya keterbatasan kit tes Covid-19 sehingga diperlukan langkah diagnosis lainnya. Dalam bidang informatika ilmuwan banyak menggunakan beberapa diagnosis salah satunya gambar X-ray pada paru-paru atau Chest X-Ray (CXR).

CXR merupakan alat yang mampu digunakan untuk mendiagnosis paru-paru atau pneumonia dalam deteksi Covid-19. Kegunaannya CXR dibandingkan dengan kit rumah sakit

* Corresponding author.

(c) (i) () Umri. K. B dan Delica. V;

licensed under Creative Commons License CC-B 
lainnya merupakan alat yang relatif terjangkau. X-Ray tidak hanya untuk mendeteksi pneumonia tetapi dapat digunakan untuk beberapa deteksi bagian tubuh lain seperti tumor, patah tulang dan bagian lainnya. Dengan adanya data CXR yang maka dapat dilakukan proses deteksi dengan menggunakan algoritma Convolutional Neural Networks (CNN). Algoritma CNN merupakan salah satu dari bagian deep learning yang merupakan jaringan feedforward terkait arus informasi yang terjadi satu arah yaitu terjadinya input menuju output [4]. Dalam penggunaan algoritma CNN pada saat ini, terdapat bayak opsi pengembangan yang dapat diterapkan untuk melakukan klasifikasi, salah satunya yaitu pengabungan dengan model transfer learning. Transfer learning sendiri merupakan proses menggunakan kembali dari model pre-trained yang sudah dilatih dengan dataset dalam skala besar oleh peneliti sebelumya [5].

Pemanfaatan CXR images dengan menggunakan transfer learning memiliki banyak model yang bisa diterapkan untuk melakukan deteks. Sebuah studi literatur menjelaskan bahwa penerapan transfer learning terbukti lebih unggul dibanding metode lainnya yang dilakukan dalam deteksi Covid-19 [6]. Penelitian Rahaman dkk [7] yang melakukan identifikasi kasus Covid-19 menggunakan CNN dan penerapan transfer learning menghasilkan nilai akurasi yang baik. Pada penelitian ini menggunakan gambar CXR menggunakan sebanyak 860 gambar (260 kasus Covid-19, 300 sehat dan 300 kasus pneumonia) telah digunakan untuk penelitian ini, di mana $70 \%$ gambar dari setiap kelas diterima untuk pelatihan, $15 \%$ digunakan untuk validasi, dan sisanya untuk pengujian. Terlihat bahwa VGG19 memperoleh akurasi klasifikasi tertinggi sebesar 89.3\% [7]. Penggunaan VGG19 juga mendapatkan hasil yang baik pada penelitian yang dilakukan oleh Apostolopoulos dkk [8] dengan menambahkan dataset penumonia sebagai variasi data menjadi 3 kelas yaitu covid, normal dan pneumonia. Penerapan transfer learning lainnya juga dilakukan oleh Makris dkk [9] dimana penelitian ini menggunakan banyak model dengan menggunakan data campuran dari CXR yang tersedia untuk publik dari pasien Covid-19, pneumonia dan normal. Hasil penelitian ini menunjukkan bahwa penggunaan model VGG16 dapat mencapai akurasi 95\%. Pada penelitian Sethy dkk [10] melakukan perbandingan beberapa model transfer learning untuk deteksi Covid-19 dan mendapatkan hasil model ResNet50 sebagai model dengan performa terbaik dibandingkan dengan 12 model lainnya dengan menghasilkan nilai akurasi 98.66\%.

Penelitian yang dilakukan oleh Mohammadi dkk [11] mendapatkan hasil yang sangat baik pada semua model yang diterapkan dengan akurasi di atas 90\%. Akurasi terbaik didapat oleh MobileNet dengan 99.1\% dan menunjukkan bahwa model MobileNet dapat dianggap sebagai model yang menjanjikan untuk mendeteksi kasus Covid-19 di masa mendatang dengan meningkatkan jumlah sampel CXR ke dataset pelatihan, akurasi dan ketahanan model semakin meningkat. Penelitian yang cukup berbeda dilakukan oleh Pham [12] yang menggunakan dataset CT-scan untuk mendeteksi Covid-19. Dalam penelitiannya 16 model diterapkan dan menunjukkan bahwa model DenseNet-201 yang merupakan model dengan hasil terbaik dalam hal akurasi untuk deteksi Covid-19 dengan hasil 96.20\% tanpa dilakukan data augmentasi. Berdasarkan studi literatur yang dilakukan pada penelitian sebelumnya, maka penelitian dilakukan dengan mencoba menerapkan transfer learning dalam mendeteksi Covid-19 menggunakan gambar CXR. Model transfer learning yang akan digunakan yaitu VGG19, VGG16, MobileNet, DenseNet201 dan ResNet50. Semua model akan diterapkan pada dataset skala besar dan kecil untuk mengetahui performa terbaik dari penerapan yang dilakukan. 


\section{Metodologi}

Penerapan bidang deep learning dengan CNN merupakan salah satu metode yang ampuh dan sering digunakan dalam klasifikasi. Proses jaringan dimulai dari input menuju output yang terjadi pada satu arah dan arsitektur yang dapat meniru cara kerja otak manusia menjadi kelebihan tersendiri [4]. Arsitektur umum yang terdiri pada CNN tentunya terbagi menjadi beberapa bagian, yaitu input, convolutiunal layer, pooling layer, fullyconnected layer serta output. Pada penelitian ini, penambahan transfer learning diterapkan pada setiap percobaan yang ada, yang berarti model arsitektur dalam CNN diubah dengan model pre-trained dengan pelatihan pada dataset lain sebelumnya. Terdapat banyak model transfer learning yang telah diciptakan, tetapi dalam penelitian sebelumnya terdapat model yang medapatkan hasil baik dalam mendeteksi covid-19 yang diterapkan dan dianalisa dalam penelitian ini. Contoh arsitektur CNN yang ditambah dengan transfer learning dapat dilihat pada Gambar 1.

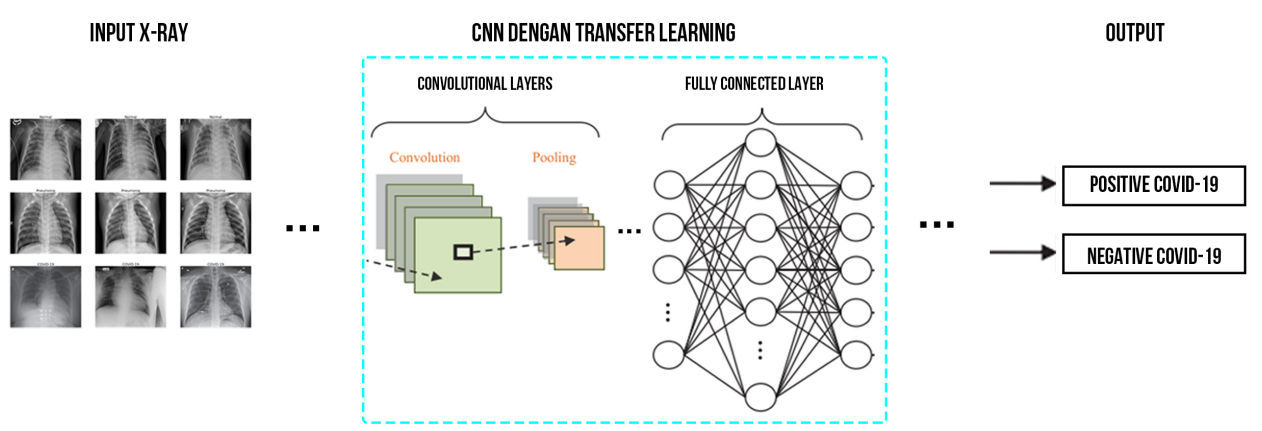

Gambar 1 Arsitektur CNN dengan transfer learning.

Pada arsitektur yang ada, input adalah awal mempersiapkan dataset CXR yang ada dan memasukannya kedalam model yang dirancang. Kemudian masuk pada convolutional layer dimana terdapat pada feature extractor yang bekerja untuk mempelajari representasi dari fitur yang masuk melalui input. Fungsi utamanya yaitu agar dapat mengidentifikasi karakter pada objek seperti tei, kurva dan warna [5]. Pada feature extractor juga terdapat pooling layer yang berfungsi sebagai downsampling atau pengurangan dimensi yang ada pada feature map agar terdapat percepatan pada komputasi yang dilakukan disebabkan parameter yang sematkin sedikit. Pada tahap ini juga diterapkan dua jenis pooling yaitu average pooling yang merupakan nilai dari rata-rata dan max pooling yang mengambil nilai terbesar [13]. Setelah itu terdapat fully connected layer dimana pada proses ini merupakan tahap akhir sebagai kumpulan dari proses konvolusi [14] sebagai penentu mana yang akan berkorelasi pada kelas tertentu. Penelitian ini memiliki alur atau tahapan yang dapat dilihat pada Gambar 2.

\section{Tahap pengumpulan dataset}

Pengumpulan dataset terdiri menjadi 2 jenis dataset yaitu dataset besar dan kecil. Pada dataset besar berisi 6000 gambar CXR yang terdiri dari 3000 gambar penderita Covid-19 dan 3000 gambar normal. Sedangkan pada dataset yang kecil yaitu berisi 200 gambar CXR yang terdiri dari 100 gambar penderita Covid-19 dan 100 gambar normal. Kedua jenis dataset yang didapat yaitu CXR Covid-19 dan CXR normal semuanya didapat melalui 


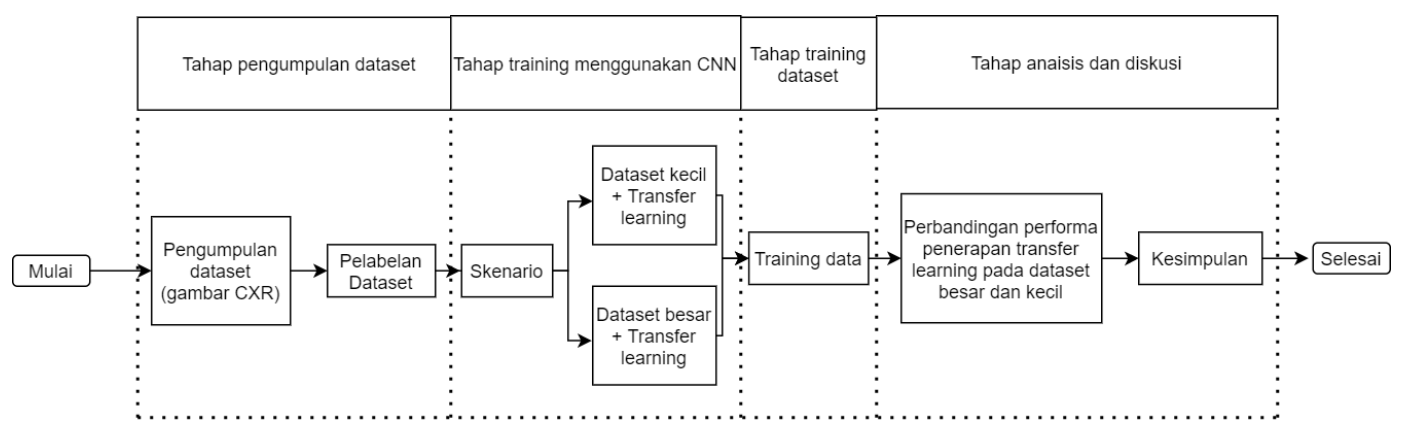

Gambar 2 Alur penelitian.

Kaggle [15] yang pada saat ini memiliki dataset dalam skala besar tentang gambar CXR Covid-19 maupun normal. Pelabelan dataset juga dilakukan pada data gambar CXR yang telah dikumpulkan, kemudian diberikan label sesuai informasi dari gambar. Label yang dilakukan pada penelitian ini adalah label untuk gambar CXR positif Covid-19 dan gambar CXR normal. Gambar yang sudah diberi label juga dibagi menjadi dua folder berbeda yaitu pada dataset besar dan kecil dan disesuaikan dengan folder masing-masing. Semua format gambar pada data ini berekstensi png.

Pada penelitian ini bersifat eksperiman yang berarti pada alur penelitian ini memiliki langkah skenario. Beberapa tahap seperti menyiapkan data gambar dengan preprocessing sebagai tahap training dan evaluasi sebelum dijalankan skenario yang direncanakan. Untuk mengetahi performa terbaik pada penerapan transfer learning yang dilakukan, maka dilakukan 2 skenario yang menerapkan dataset besar dan kecil pada penerapan CNN. Terdapat 5 model pre-trained yaitu VGG19, VGG16, MobileNet, DenseNet201 dan ResNet50 yang masing-masing diuji menggunakan dataset besar maupun kecil.

Skenario 1 yaitu penerapan dataset kecil dengan dengan transfer learning, sedangkan skenario 2 yaitu penerapan dataset besar dengan transfer learning. Arsitektur yang digunakan dalam penelitian ini merupakan pengabungan dari CNN dengan 5 model yang sudah terbukti baik digunakan oleh peneliti sebelumnya dalam mendeteksi Covid-19 menggunakan CXR. Semua kombinasi percobaan dilakukan pada masing-masing skenario sehingga dapat dianalisa performa terbaik dari penerapan transfer learning dalam dataset besar maupun kecil.

\section{Tahap training dataset}

Setelah menentukan skenario sebelumnya yaitu transfer learning dengan dataset yang disiapkan, tahap ini mencoba dataset besar dan kecil yang telah disiapkan dengan sebelumnya pada masing-masing skenario. Training data bertujuan untuk melatih kedua skenario agar pada hasil akhir dapat memberikan nilai performa yang tinggi.

\section{Tahap analisis dan diskusi}

Pada tahap terakhir ini, merupakan tahap untuk mengevaluasi hasil berdasarkan skenario yang sudah dibuat sebelumnya. Terdapat dua evaluasi yang dilakukan yaitu,

1. Mengetahi performa penerapan dataset besar dan kecil pada deteksi yang dilakukan.

2. Membandingkan akurasi terbaik dari semua model transfer learning yang diterapkan dalam mendeteksi Covid-19 menggunakan gambar CXR. 


\section{Hasil dan pembahasan}

Pada pengumpulan data gambar dilakukan dengan data open source yang dapat diakses oleh publik. Kedua jenis dataset Covid-19 dan normal CXR semuanya didapat melalui situs Kaggle (https://www.kaggle.com/tawsifurrahman/covid19-radiography-database) yang didalamnya sudah terdapat jenis gambar CXR Covid-19, normal dan pnoumonia dalam skala besar. Total dataset yang digunakan dalam penelitian ini sebanyak 6000 gambar CXR yang dibagi menjadi 3000 Covid-19 dan 3000 Normal. Sedangkan dalam dataset kecil hanya mengambil 200 gambar CXR yang dibagi menjadi 100 Covid-19 dan 100 normal. Kedua jenis gambar diambil pada 5 Agustus 2021 dengan sampel data yang dapat dilihat pada Gambar 3 dan 4.

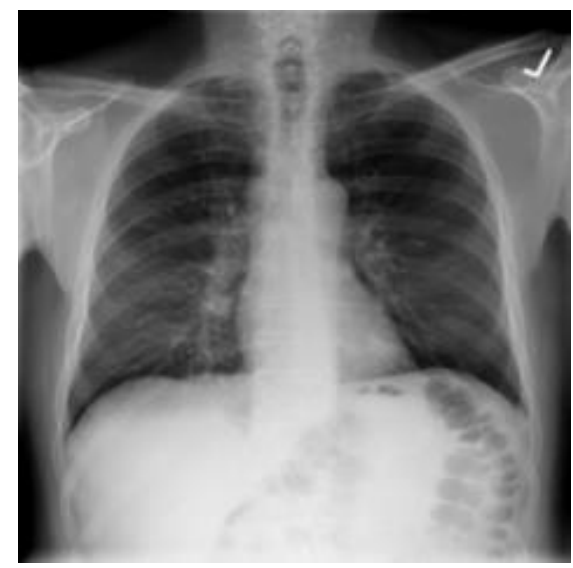

Gambar 3 Paru-paru normal.

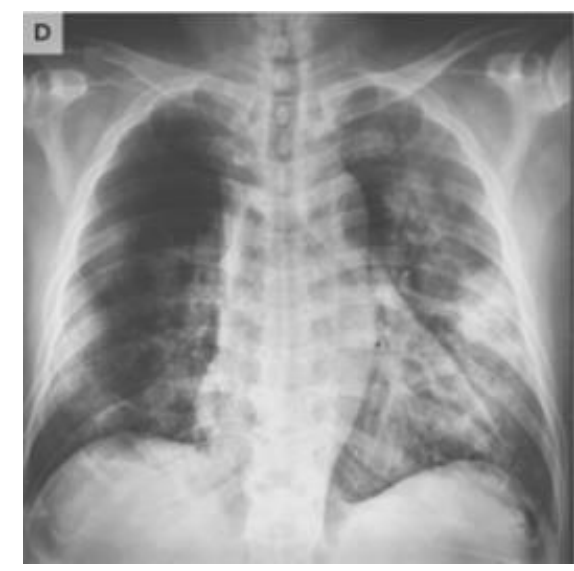

Gambar 4 Paru-paru pnoumonia.

Setelah pengumpulan data dan pelatihan terhadan kedua skenario selesai dilakukan, kemudian dilakukan pengujian dengan data uji agar bisa mengetahui tingkat akurasi dan kinerja dari masing-masing model transfer learning pada setiap skenario. Pada tahap ini terdapat beberapa usulan parameter yang telah diatur seperti raiso dari dataset yaitu 70:15:15, yang dibagi menjadi 70\% data untuk training, 15\% data sebagai validation dan $15 \%$ data untuk testing atau uji evaluasi dari penerapan model. Pada kasus dataset besar digunakan 10 epoch dan batch size 100 pada setiap uji yang dilakukan pada setiap pre-trained model sedangkan pada kasus dataset kecil digunakan 40 epoch dan batch size 20. Berikut merupakan tabel hasil dari pengujian yang dilakukan pada kasus dataset kecil yang dapat dilihat pada Tabel 1.

Tabel 1 Hasil penelitian skenario 1.

\begin{tabular}{l|l|l|l|l|l|l}
\hline \multicolumn{7}{c}{ Skenario 2 - Transfer learning pada dataset besar } \\
\hline No & Transfer learning & Accuracy & Precision & Recall & F1 & Epoch \\
\hline 1 & VGG19 & $\mathbf{9 6 . 7 7 \%}$ & $92.90 \%$ & $100 \%$ & $96.30 \%$ & 40 \\
2 & VGG16 & $61.29 \%$ & $100 \%$ & $7.70 \%$ & $14.30 \%$ & 40 \\
3 & MobileNet & $87.10 \%$ & $100 \%$ & $69.20 \%$ & $81.80 \%$ & 40 \\
4 & DenseNet201 & $90.23 \%$ & $91.70 \%$ & $84.60 \%$ & $88.00 \%$ & 40 \\
5 & ResNet50 & $41.94 \%$ & $41.90 \%$ & $100 \%$ & $59.10 \%$ & 40 \\
\hline
\end{tabular}

Pada Tabel 2 dapat terlihat hasil percobaan dari semua model transfer learning pada skenario pertama. Hasil yang didapat pada skenario ini menunjukkan bahwa model pre- 
trained VGG19 mendapatkan performa terbesar dibandingkan model lain dengan akurasi 96.77\%. Selanjutnya pada Tabel 2 merupakan hasil dari penerapan skenario 2.

Tabel 2 Hasil penelitian skenario 2.

\begin{tabular}{l|l|l|l|l|l|l}
\hline \multicolumn{7}{c}{ Skenario 2 - Transfer learning pada dataset besar } \\
\hline No & Transfer learning & Accuracy & Precision & Recall & F1 & Epoch \\
\hline 1 & VGG19 & $97.56 \%$ & $97.40 \%$ & $97.80 \%$ & $97.60 \%$ & 10 \\
2 & VGG16 & $97.78 \%$ & $98.90 \%$ & $96.70 \%$ & $97.80 \%$ & 10 \\
3 & MobileNet & $\mathbf{9 8 . 1 1} \%$ & $98.90 \%$ & $97.40 \%$ & $98.10 \%$ & 10 \\
4 & DenseNet201 & $97.23 \%$ & $98.90 \%$ & $95.60 \%$ & $97.20 \%$ & 10 \\
5 & ResNet50 & $49.17 \%$ & $60.00 \%$ & $0.70 \%$ & $1.30 \%$ & 10 \\
\hline
\end{tabular}

Setelah melihat penerapan transfer learning pada Tabel 3, dapat diketahui bahwa perbandingan semua model menunjukkan hasil yang berbeda dibanding skenario 1 . Pada skenario 2 penggunakan model MobileNet terbukti lebih unggul jika diuji menggunakan jumlah dataset yang besar. Hasil yang didapat dapat dilihat bahwa MobileNet memiliki performa sedikit lebih tinggi dibanding model lainnya dengan akurasi 98.11\%. Perbandingan nilai akurasi yang dihasilkan oleh semua model transfer learning dari skenario pertama maupun kedua dutampilkan dalam Gambar 5.

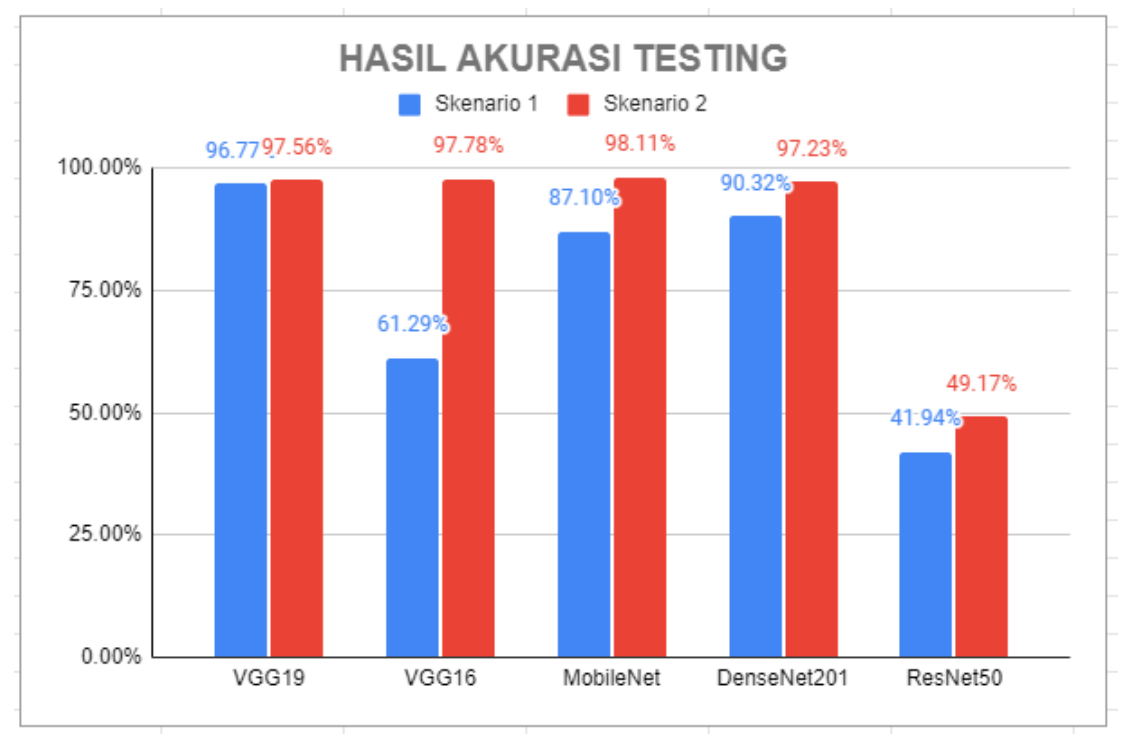

Gambar 5 Grafik hasil akurasi testing.

Dari hasil yang terdapat pada Gambar 5, diketahui bahwa semua model pengujian yang dilakukan pada skenario 2 mendapatkan hasil yang lebih tinggi dari masing-masing model pada skenario 1. Pada performa terbaik diketahi bahwa pempenerapan model transfer learning MobileNet pada kasus dataset besar atau skenario 2 mendapatkan hasil akurasi tertinggi dibanding model lainnya dan akurasi terkecil didapat oleh ResNet50 yang diterapkan dengan kasus dataset kecil atau skenario 1. Perbedaan kenaikan akurasi dari skenario 1 ke skenario 2 pada transfer learning VGG19, MobileNet, DenseNet201 dan ResNet50 tidak terlalu jauh, tetapi pada VGG16 dapat dapat dilihat perbedaan yang cukup besar antara skenario 1 dan skenario 2, yang berarti pre-trained VGG16 lebih cocok jika digunakan pada kasus penelitian dataset yang besar. 
Selain dari gambar grafik di atas yang menunjukkan dataset besar lebih baik pada akurasi, pada proses training juga dapat diamati pada Gambar 6 dan 7 yang menunjukkan perbedaan grafik pada MobileNet dari kedua skenario yang diterapkan.

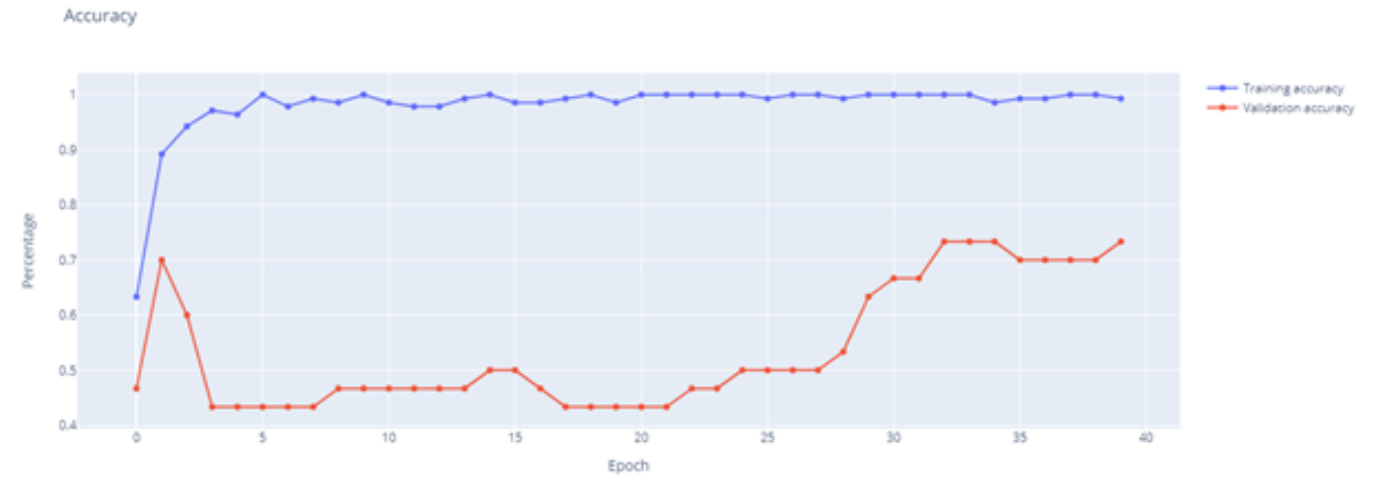

Gambar 6 MobileNet pada dataset kecil.

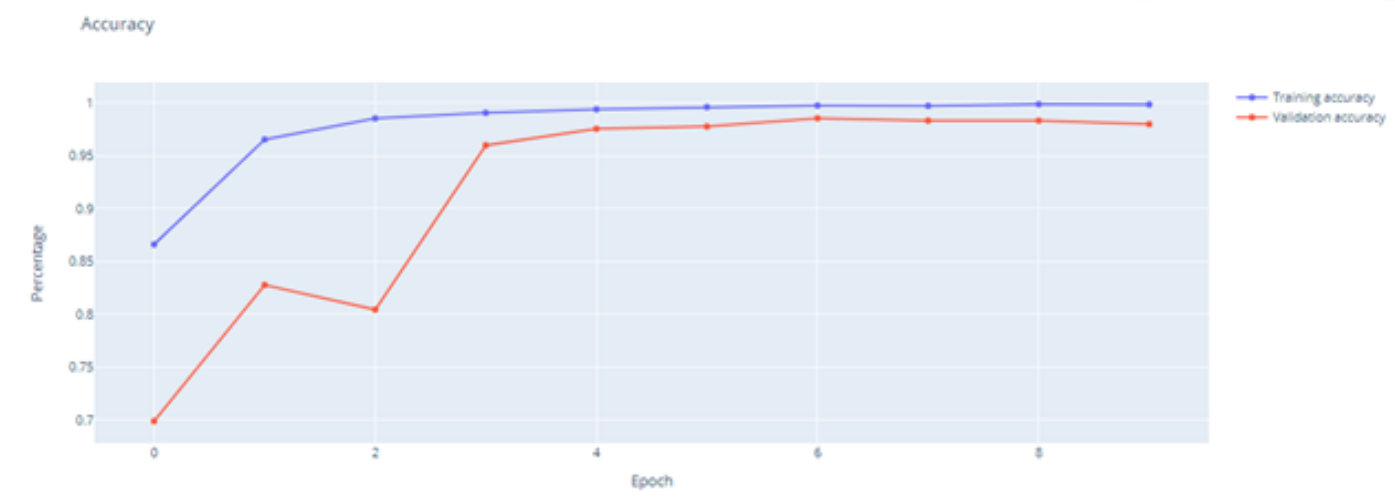

Gambar 7 MobileNet pada dataset besar.

Pada Gambar 6 dan 7 terdapat berbedaan grafik yang digunakan pada kasus dataset besar dan kecil. Terlihat bahwa grafik yang dihasilkan dari skenario 1 mengalami proses training yang tidak dapat diikuti dengan baik oleh proses validasi sehingga menyebabkan overfitting. Sedangkan pada skenario 2 dapat dilihat grafik yang ada berjalan cukup baik.

\section{Kesimpulan}

Berdasarkan hasil analisis dan pengujian yang telah dilakukan pada 2 skenario yang berisi penerapan transfer learning pada kasus dataset besar dan kecil dalam mendapatkan performa terbaik dalam mendeteksi Covid-19 menggunakan gambar CXR dapat disimpulkan bahwa semua penerapan kasus dataset besar dapat meningkatkan performa dari semua model yang diujikan. Penerapan terbaik dari semua model yang dicoba yaitu MobileNet dengan hasil akurasi $98.11 \%$ dan paling rendah didapat oleh ResNet50 dengan akurasi $41.94 \%$. Penerapan dataset besar dalam deteksi ini sangat di sarankan karena memiliki performa yang terbukti lebih baik. Pada dataset kecil juga mendapatkan hasil yang baik pada beberapa model 
yang diterapkan, tetapi dalam proses deteksi kurang disarankan karena terdapat overfitting saat model diterapkan. Beberapa saran yang dapat dijadikan pedoman untuk melakukan pengembangan penelitian ini yaitu mencoba menerapkan data augmentation terutama pada dataset yang terbatas atau skala kecil untuk memperkaya data yang ada.

\section{Pustaka}

1 K. Roosa, Y. Lee, R. Luo, A. Kirpich, R. Rothenberg, J. Hyman, P. Yan, dan G. b. Chowell, "Real-time forecasts of the covid-19 epidemic in china from february 5th to february 24th, 2020," Infectious Disease Modelling, vol. 5, pp. 256-263, 2020.

2 L. Yan, H.-T. Zhang, Y. Xiao, M. Wang, Y. Guo, C. Sun, X. Tang, L. Jing, S. Li, M. Zhang et al., "Prediction of criticality in patients with severe covid-19 infection using three clinical features: a machine learning-based prognostic model with clinical data in wuhan," MedRxiv, 2020.

3 "Covid live update: 202,597,134 cases and 4,294,653 deaths from the coronavirus worldometer." https://www.worldometers.info/coronavirus/,diakses 7 Agustus 2021.

4 W. Rawat dan Z. Wang, "Deep convolutional neural networks for image classification: A comprehensive review," Neural computation, vol. 29, no. 9, pp. 2352-2449, 2017.

5 R. Siddiqi, "Effectiveness of transfer learning and fine tuning in automated fruit image classification," in Proceedings of the 2019 3rd International Conference on Deep Learning Technologies, 2019, pp. 91-100.

6 B. K. Umri, E. Utami, dan M. P. Kurniawan, "Tinjauan literatur sistematik tentang deteksi covid-19 menggunakan convolutional neural networks," Creative Information Technology Journal, vol. 8, no. 1, pp. 9-21, 2021.

7 M. M. Rahaman, C. Li, Y. Yao, F. Kulwa, M. A. Rahman, Q. Wang, S. Qi, F. Kong, $\mathrm{X}$. Zhu, dan X. Zhao, "Identification of covid-19 samples from chest x-ray images using deep learning: A comparison of transfer learning approaches," Journal of X-ray Science and Technology, no. Preprint, pp. 1-19, 2020.

8 I. D. Apostolopoulos dan T. A. Mpesiana, "Covid-19: automatic detection from x-ray images utilizing transfer learning with convolutional neural networks," Physical and Engineering Sciences in Medicine, vol. 43, no. 2, pp. 635-640, 2020.

9 A. Makris, I. Kontopoulos, dan K. Tserpes, "Covid-19 detection from chest x-ray images using deep learning and convolutional neural networks," in 11th Hellenic Conference on Artificial Intelligence, 2020, pp. 60-66.

10 P. Sethy dan S. Behera, "Detection of coronavirus disease (covid-19) based on deep features, preprints, 2020," DOI: https://doi. org/10.20944/preprints202003, vol. 300, p. v1.

11 R. Mohammadi, M. Salehi, H. Ghaffari, A. Rohani, dan R. Reiazi, "Transfer learningbased automatic detection of coronavirus disease 2019 (covid-19) from chest x-ray images," Journal of Biomedical Physics 83 Engineering, vol. 10, no. 5, p. 559, 2020.

12 T. D. Pham, "A comprehensive study on classification of covid-19 on computed tomography with pretrained convolutional neural networks," Scientific reports, vol. 10, no. 1, pp. $1-8,2020$.

13 W. S. E. Putra, "Klasifikasi citra menggunakan convolutional neural network (cnn) pada caltech 101," Jurnal Teknik ITS, vol. 5, no. 1, 2016.

14 S. Hijazi, R. Kumar, C. Rowen et al., "Using convolutional neural networks for image recognition," Cadence Design Systems Inc.: San Jose, CA, USA, pp. 1-12, 2015. 
PUSTAKA

15 "Covid-19 radiography database | kaggle." https://www.kaggle.com/tawsifurrahman/ covid19-radiography-database/,diakses 14 Juni 2021. 